Ekinci, R., Gençyürek, A. G. (2021). "Dynamic Connectedness between Sector Indices: Evidence from Borsa Istanbul”, Eskişehir Osmangazi Üniversitesi iiBF Dergisi, 16(2), 512 - 534.

Doi: 10.17153/oguiibf.879784

Başvuru: 13.2.2021 Kabul: 4.5.2021

Araştırma Makalesi/Research Article

\title{
Dynamic Connectedness between Sector Indices: Evidence from Borsa Istanbul
}

\begin{tabular}{|c|c|}
\hline $\begin{array}{l}\text { Sektör Endeksleri Arasındaki Dinamik Bağlantılılık: } \\
\text { Borsa İstanbul Örneği }\end{array}$ & $\begin{array}{l}\text { Dynamic Connectedness between Sector Indices: } \\
\text { Evidence from Borsa Istanbul }\end{array}$ \\
\hline Öz & Abstract \\
\hline $\begin{array}{l}\text { Çalışmanın amacı BiST Finans, Sanayi, Teknoloji, Turizm, } \\
\text { Ulaştırma, Gıda ve Perakende -Ticaret sektörleri } \\
\text { arasındaki şok ve volatilite yayılımını analiz etmektir. Bu } \\
\text { doğrultuda } 5 \text { Ocak } 2010 \text { ile } 4 \text { Aralık } 2020 \text { tarihleri } \\
\text { arasındaki günlük veriler Antonakakis vd. (2019) } \\
\text { tarafından geliştirilen TVP- VAR Diebold Yılmaz Yayılım } \\
\text { Endeksi yöntemiyle analiz edilmiştir. Yapılan analizler } \\
\text { sonucunda sanayi ve finans sektörünün şok ve volatilite } \\
\text { yayılımında öncül; diğer sektörlerin ise, genellikle ardıl } \\
\text { konumda oldukları tespit edilmiştir. }\end{array}$ & $\begin{array}{l}\text { The aim of the study is to analyze the shock and volatility } \\
\text { spillover between BIST Finance, Industry, Technology, } \\
\text { Tourism, Transportation, Food, and Retail-Trade sectors. } \\
\text { In this direction, daily data obtained between January } 5 \text {, } \\
2010 \text {, and December 4, 2020, were analyzed using a new } \\
\text { method named TVP-VAR Diebold YIlmaz Spillover Index } \\
\text { developed by Antonakakis et al. (2019). Our results } \\
\text { indicate that the industrial and financial sectors are in } \\
\text { the leading position in terms of the shock and volatility } \\
\text { spillover, while other sectors generally are in the lagging } \\
\text { position. }\end{array}$ \\
\hline $\begin{array}{l}\text { Anahtar Kelimeler: BiST, Sektör Endeksleri, Getiri, } \\
\text { Volatilite, Yayılım Endeksi }\end{array}$ & $\begin{array}{l}\text { Keywords: BIST, Sector Indices, Return, Volatility, } \\
\text { Spillover Index }\end{array}$ \\
\hline JEL Kodları: C22, C58, G14 & JEL Codes: C22, C58, G14 \\
\hline \multicolumn{2}{|l|}{$\begin{array}{c}\text { Araştırma ve Yayın } \\
\text { Etiği Beyanı }\end{array}$} \\
\hline \multicolumn{2}{|c|}{$\begin{array}{l}\text { Çalışmanın teorik altyapısının oluşturulması, ampirik analizlerin yapılması ve yabancı dil kontrolü } \\
\text { noktasında iş bölümü eşit bir şekilde gerçekleştirilmiştir. }\end{array}$} \\
\hline \multicolumn{2}{|c|}{ Yazarlar açısından ya da üçüncü taraflar açısından çalışmadan kaynaklı çıkar çatışması bulunmamaktadır. } \\
\hline
\end{tabular}

\footnotetext{
${ }^{1}$ Dr. Öğr. Üyesi, Bakırçay Üniversitesi, İktisadi ve İdari Bilimler Fakültesi, iktisat, ramazan.ekinci@bakircay.edu.tr 2 Dr. Öğr. Üyesi, Munzur Üniversitesi, İktisadi ve İdari Bilimler Fakültesi, Bankacılık ve Finans, ahmetgalipgencyurek@munzur.edu.tr
} 


\section{Introduction}

The Efficient Markets Hypothesis indicates that the stock market reflects both idiosyncratic information and information that concern the entire economy (Malkiel, 1989: 1313). There is no incentive to obtain information as the market equilibrium will hardly change in such a market (Stiglitz, 1981: 1). However, according to studies addressing the subject, it is concluded that the Efficient Markets Hypothesis is not valid and that the information (national, international, etc.) is a source of gaining more than the market average return. In an environment where possessing information is profitable, information transfer becomes an important issue. Financial liberalization and technology concepts are considered to be effective in information transmission. Integration between markets (money-capitalcommodities) increases with financial liberalization and the development of technology. Because financial liberalization accelerates the mobility of capital, which is one of the production factors and expedites obtaining of information. Advances in technology, on the other hand, accelerate the information transfer process and shorten the time of information transmission between markets (Mateus et al., 2017: 279). Increasing integration between markets thus causes the change that occurs in one of or in several markets to have an impact on other market/markets and/or to initiate co-movement of the markets.

Integration between financial markets manifests itself as shock and volatility spillover. Shock spillover is the transmission of a random shock from one market to another (Chakrabarty et al., 2015: 36). Volatility spillover is risk and information transmissions (Nazlıoğlu et al., 2015: 2). Furthermore, volatility spillover occurs when changes in the return of one asset cause changes in the volatility of another asset (Duncan and Kabundi, 2013:566). Studies conducted regarding this purpose in the literature are named spillover, pass-through, co-movement, transmission, and connectedness. In recent years, in cross-market spillover studies, markets have been examined in terms of their internal dynamics, that is, in terms of the relations between sectors. According to some studies, it is determined that sectoral diversification is more risk-reducing than cross-country diversification (Cavaglia et al., 2000:41). Despite better diversification advantages, spillovers among sector indices still have not received special attention (Mensi et al., 2020: 3).

The upward or downward fluctuations in prices due to inter-sectoral relations are generally transmitted to other sectors, starting from one or more sectors (Yin et al. 2020: 1). Sector indices are important indicators used for portfolio performance for stock market participants (Zhang et al., 2020: 3). By determining the relationships between stock market sector indices, investors can perform asset allocation to avoid risk and earn higher returns (Yin et al., 2020: 1). Policymakers can also obtain information regarding which sectors they would better develop policies to take a rapid step towards the economy by looking at the inter-sectoral shock, information, and risk transmission mechanism. This is because each sector is linked to the economy to a considerable extent. For instance, the financial sector enables the transmission of monetary policy shocks towards the macroeconomy. In this case, it is anticipated that this shock will be transferred from the financial sector to other sectors (Chatziantoniou et al., 2020: 1).

The aim of this study is to examine the shock and information transfer mechanisms between stock markets' sector indices. The study aims to provide answers for the following three questions: Which is the leading sector of Turkey's economy? How is the connectedness between the sectors manifested? Does the connectedness relationship change depending on 
time? To answer the research questions, the TVP-VAR Diebold Yilmaz Index method, which is a VAR-based Diebold Yilmaz Spillover Index method developed by Antonakakis et al. (2019) was used.

As a result of the static and dynamic analyzes, the industrial sector is determined as the leading sector. It is revealed that the financial sector followed the industrial sector. In the pairwise relationship between the industrial sector and the finance sector, it is understood that the finance sector is a net shock and volatility recipient. It is also observed that the fluctuations depending on the time shown by the Total Spillover Index, indicate significant events.

This study is expected to contribute to the literature in terms of three aspects. The method utilized in the study is used for the first time in the literature for the analysis of Borsa Istanbul indices. Secondly, the spillover effect is analyzed on a sectoral basis. Finally, it provides easy-to-understand information to policymakers and investors who may apply it for portfolio diversification and shows its alteration in time. In the following chapters of the study, the literature, methodology, implementation, and conclusion parts are included respectively.

\section{Literature Review}

In studies examining the relations between markets, more studies are examining the relationship between commodity markets and stock markets (eg Malik and Ewing, 2009; Arouri et al., 2012; Creti et al., 2013; Mensi et al., 2013; Kang et al., 2015; Basher and Sadorsky, 2016; Bai and Kong, 2018; Balcılar et al., 2019; Khalfaoui et al., 2019; Antonakakis et al., 2019; Belhassine, 2020, Hassan et al., 2020; Mandacı et al., 2020) or including analysis between regional or international stock markets (eg Diebold and Yılmaz, 2009; Hammoudeh et al., 2009; Singh et al., 2010; Xiao and Dhesi, 2010; Li and Giles, 2014; Mensi et al., 2016; Jebran et al., 2017; Baumöhl et al., 2018). The most important limitation of these studies is that they only focused on general trends between stock markets or asset classes. While the results extrapolated here provide a general forecast regarding the connectedness tendency, they do not provide information about the dynamics of different sectors of an economy. However, considering the direct connectedness of each sector with the general economic performance, the results to be obtained from the studies conducted on the basis of the sector are expected to demonstrate clearer and reliable results about the general trend of the economy. For instance, the financial sector plays a key role in the transmission of monetary policy shocks to the economy. Therefore, shock transmission from the financial sector to other sectors is expected to be more than other transmission channels. At the same time, this sector's connection with other sectors will change over time as financial markets are constantly improving.

With respect to the analysis of the relations between markets in the literature, VAR, VEC, Granger Causality, ARDL, Todo-Yamomoto, Univariate Autoregressive Conditional Heteroscedasticity, Multivariate Autoregressive Conditional, Heteroscedasticity, Variance Causality (Hong, Hafner-Herwartz), and Diebold Yilmaz Spillover Index models are used. Studies examining the relationships between sector indices are classified below in developed and emerging markets.

Arbelaez et al. (2001) examined Colombia's stock market considering the period span from 1988 to 1994. In their study, they utilized Granger Causality and VEC models. They denoted 
that there were pairwise relations between many sector indices. Patra et al. (2008) investigated Greece's stock market to find out the most dominant sector among sectoral indices. To do this, they used the Granger Causality method. They asserted that the banking sector was the most influential in the Greek economy, followed by the industrial sector. Ahmed (2016) also found that the banking index was the leading sector in the Egyptian stock market. Kouki et al. (2011) analyzed emerging stock markets by using VAR, BEKK, CCC, and DCC-GARCH methods. They remarked that the banking and real estate sector indices and the crude oil market had a high degree of integration relationships, while the financial services and industry sectors had a less integrated structure.

Duran and Sahin (2006), Tokat (2010), Vardar et al. (2012), Eyüboglu and Eyüboglu (2019), Kırkpınar (2019), Kocaarslan (2020), Senol (2020) and Topaloglu (2020) investigated the Turkey stock market considering different periods and metholodogies. Duran and Sahin (2006), Vardar et al. (2012), and Eyüboglu and Eyüboglu (2019) analyzed the connection between sectoral indices by using Granger Causality and VAR models. Duran and Sahin (2006) found some relations between sectoral indices. The banking index was the most important sector in the study of Vardar et al. (2012), but Eyüboglu and Eyüboglu (2019) did not find any relationship. On the other hand, Tokat (2010), Kırkpınar (2019), Kocaarslan (2020), Senol (2020), and Topaloglu (2020) focused on variance spillover between sectoral indices. In these studies, authors used BEKK-GARCH, Hong Variance Causality, Hafner-Herwartz Variance Causality, and DCC-GARCH. Tokat (2010) showed that there was a volatility spillover between industry and financial, service and technology sectors. Another study, Kırkpınar (2019) showed that there was a bidirectional relationship in variance between BIST service and financial indices. Volatility transmission from technology index to industry, services, and financial index and from industrial index to service and financial index was determined in Kocaarslan (2020). Senol (2020) concluded that the financial sector was affected by industry, retail, and service sector volatilities. Topaloglu (2020) also found that there was a volatility spillover from the financial index to the industrial index.

In the literatüre studies on developed countries are as follows:

Wang et al. (2005), Chen et al. (2019), and Yin et al. (2020) looked into the relationship between Chinese sectoral indices using VAR, Granger Causality, and Diebold Yılmaz Spillover Index respectively. Wang (2005) found that the finance sector is the most important indicator among indexes. Chen et al. (2019), and Yin et al. (2020) found the leading role of the industrial sector.

Ewing (2002), Hasan and Malik (2007), Wang (2010), Barunik et al. (2015), and Mensi et al. (2020) utilized VAR, BEKK-GARCH, Parametric and Non-parametric Granger Causality, and Diebold YIlmaz Spillover Index to investigate the USA stock market. Ewing (2002) concluded that the industry sector was explained mostly by the finance sector and the capital instruments sector explained mostly by the industry sector. Hasan and Malik (2007) denoted that the consumer sector was indirectly affected by the financial sector shock and volatility, the financial sector was indirectly affected by the shock and volatility of the consumer and technology sectors, the technology sector was directly and indirectly affected by the financial sector shock and directly and indirectly the volatility of other sectors, the energy sector was affected by the industrial sector shock and volatility indirectly, the health sector was indirectly affected by the industrial sector shock and volatility, and the industrial sector was indirectly affected by the shock and volatility of the energy sector. Wang (2010) concluded that the 
finance sector was the most important leading indicator among sector index volatilities. Barunik et al. (2015) found that the telecommunication and health sectors exhibited a higher level of asymmetric spillover compared to the finance, information technology, and energy sectors. Mensi et al. (2020) asserted that the biggest net volatility transmitter was the consumer service sector, while the technology and raw materials sectors were the biggest net volatility recipients. When we compare the results got from the literature, the financial or banking, and industrial sectors had a leading role in both developed and emerging stock markets. We make an inference that the change of leading sector role depends on the period of analysis.

\section{Methodology}

In this study, dynamic connectedness is measured using Antonakakis and Gabauer's (2019) method, which combined the time-varying VAR (TVP-VAR) model with the popular model of Diebold and Yilmaz $(2009,2012)$. We have used the TVP-VAR model in this study because it has some advantages over the standard rolling-window-based VAR model. First, it overcomes the arbitrary window size selection problem that causes fattened parameter estimates. Second, since the TVP-VAR model is estimated based on the Kalman filter procedure to calculate the variance-covariance matrix, valuable observations are not lost when calculating the time-varying coefficients. Third, the model is not sensitive to outliers. Lastly, it enables analysis with a low-frequency data set (Antonakakis et al., 2019)

Let $Y_{t}$ be a $(\mathrm{N} \times 1)$ dimensional vector consisting of $\mathrm{N}$ number of sectors. The TVP-VAR model can be formulated in the following sets of equations:

$$
\begin{array}{ll}
Y_{t}=\Phi_{t} Y_{t-1}+u_{t} ; \quad & u_{t} \backslash \Omega_{t-1} \sim N\left(0, S_{t}\right) \\
\Phi_{\mathrm{t}}=\Phi_{\mathrm{t}-1}+v_{t} ; & v_{t} \backslash \Omega_{t-1} \sim N\left(0, R_{t}\right)
\end{array}
$$

$\Omega_{\mathrm{t}-1}$ here represents the set of information available in period $t-1$. $Y_{t-1}$ is the lagging vector of the dependent variable. $\Phi_{\mathrm{t}}$ is a time-varying $(N \times N p)$ dimensional coefficient matrix. $u_{t}$ and $v_{t}$ are two different error terms defined by the vector $(N \times 1)$. $S_{t}$ and $R_{t}$ are $\left(N_{p} \times N_{p}\right)$ matrices that show the time-varying variance-covariance matrices of the error terms $u_{t}$ and $v_{t}$, respectively.

After estimating time-varying parameters and variances using the TVP-VAR technique, based on generalized impulse response functions (GIRF) and generalized forecast errorvariance decompositions (GFEVD), Diebold and YIlmaz's (2014) generalized connectedness procedure can be estimated:

$$
Y_{t}=\Phi_{t} Y_{t-1}+u_{t}=A_{t} u_{t}
$$

Where $A_{t}=\left(\begin{array}{llll}A_{1, t} & A_{2, t}, \ldots & A_{p, t}\end{array}\right)^{\prime}, i \neq 0$ (otherwise $\left.I_{N}\right), A_{i, t}=\sum_{k=1}^{p} \Phi_{1, t} A_{i-k, t}$ is a matrix of $(N \times N)$ dimensional parameters that prove the equation. In this case, generalized impulse response functions (GIRF) can describe the responses of all variables following a shock in variable $i$.

Antonakakis et al. (2019) calculate the differences between J-step-forward looking estimates when the $i$ variable is not stimulated with a shock. In terms of notation, let $\mathrm{J}$ be the forecast horizon and the selection vector on point $\delta_{i, j} j$ equal to 1 or otherwise 0. In this case, denoted by $\Psi_{j, t}^{g}(J)$, GIRF can be formulated as follows:

$$
\operatorname{GIRF}\left(J, \delta_{i, j}, \Omega_{\mathrm{t}-1}\right)=E\left(Y_{t+j} \backslash u_{j, t}=\delta_{i, j}, \Omega_{\mathrm{t}-1}\right)-E\left(Y_{t+j} \backslash \Omega_{\mathrm{t}-1}\right)
$$




$$
\Psi_{j, t}^{g}(J)=S_{j j, t}^{-\frac{1}{2}} A_{J, t} S_{t} u_{j, t}
$$

Also, GFEVD for horizon J, denoted by $\Pi_{j, t}^{g}(J)$ can be computed as follows:

$\Pi_{j, t}^{g}(J)=\frac{\sum_{t=1}^{J-1} \Psi_{i j, t}^{2, g}}{\sum_{j=1}^{N} \Sigma_{t=1}^{J-1} \Psi_{i j, t}^{2, g}}$

$\Pi_{j, t}^{g}(J)$ can be interpreted as the variance ratio indicating the weight of a variable among other variables. GFEVD verifies $\sum_{j=1}^{N} \Pi_{j, t}^{N}(J)=1$ ve $\sum_{i, j=1}^{N} \Pi_{j, t}^{N}(J)=N$ equations.

Different connectedness indices can be generated using GFEVD. The first index is the "total connectedness" index, which shows how the shock in a variable disperses to other variables in the system and is computed as below:

$$
H_{t}^{g}(J)=\frac{\sum_{i, j=1, i \neq j}^{N} \Pi_{i j, t}^{g}(J)}{N} \times 100
$$

Secondly, the linear connectedness that $i$ variable gets from $j$ variables can be calculated. The index is called "total directional connectedness from others" and is computed as follows:

$$
H_{i \leftarrow j, t}^{g}(J)=\frac{\sum_{i, j=1, i \neq j}^{N} \Pi_{i j, t}^{g}(J)}{\sum_{j=1}^{N} \Pi_{i j, t}^{N}(J)} \times 100
$$

Similarly, the transmission of the shock received by the $i$ variable to all other $j$ variables can be calculated. The index, called "total directional connectedness to others" is computed as follows:

$$
H_{i \rightarrow j, t}^{g}(J)=\frac{\sum_{i, j=1, i \neq j}^{N} \Pi_{j i, t}^{g}(J)}{\sum_{j=1}^{N} \Pi_{j i, t}^{N}(J)} \times 100
$$

Finally, the "net total directional connectedness" index, which shows the difference between two indices, can be computed as follows:

$$
H_{i, t}^{g}(J)=H_{i \rightarrow j, t}^{g}(J)-H_{i \leftarrow j, t}^{g}(J)
$$

This index measures the "power" of variable $i$ or its effect on all variable systems. If $H_{i, t}^{g}(J)>0$, the net effect of the $i$ variable on the system is positive. If $H_{i, t}^{g}(J)<0$, then variable $i$ is explained by the system.

\section{Data Set}

The data set of the study consists of daily index values of 7 different sectors in BIST. The sectors included in the analysis are Finance, Industry, Technology, Tourism, Transport, Food, and Retail-Trade. The data set includes the dates from January 5, 2010, to December 4, 2020, and consists of a total of 2745 observations. The variables that make up the data set were obtained from investing.com. Series are included in the analysis after transforming them into a return series using the logarithmic difference formula below. Graphs of price and return series are shown in Figure 1 and Figure 2.

$$
r_{t}=100 \times\left[\ln \left(P_{t}\right)-\ln \left(P_{t-1}\right)\right]
$$


Figure 1. Sector Indices' Price Graphics
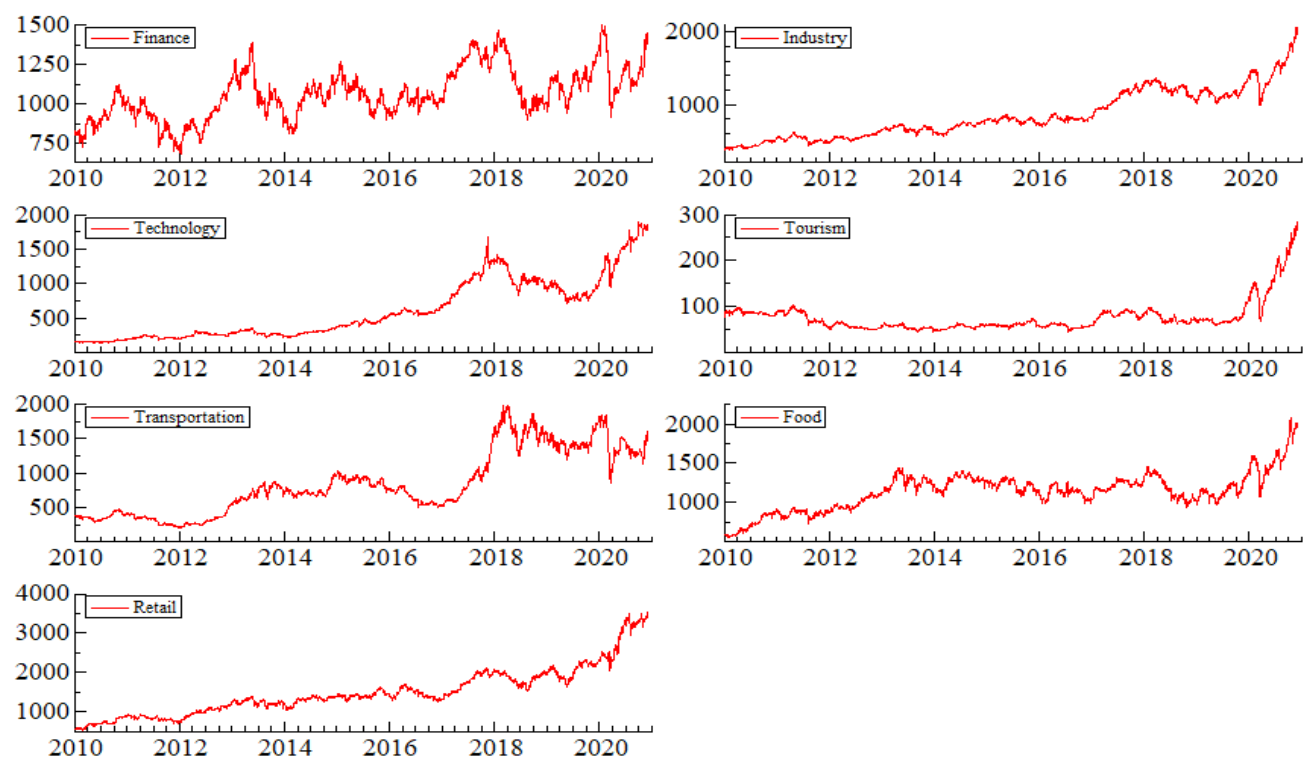

Sector indices in Figure 1 generally display a positive trend. Especially in the period that started with the Covid-19 crisis, significant structural breaks are observed in the series. The finance sector, on the other hand, follows a fluctuating course throughout the entire period, especially in crisis periods.

Figure 2. Sector Indices' Return Graphics
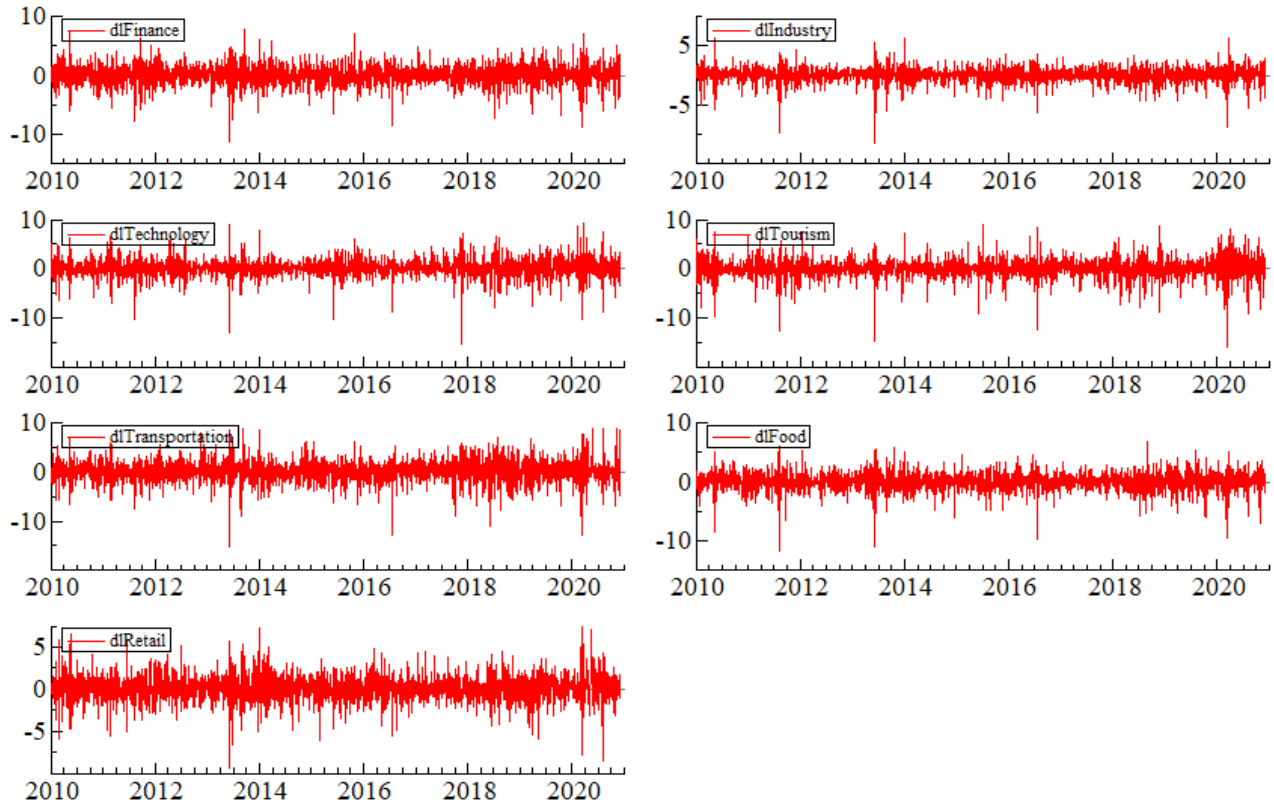
Table 1. Descriptive Statistics

\begin{tabular}{llllllll}
\hline & Finance & Industry & Technology & Tourism & Transport & Food & Ret-Tra. \\
\hline Mean & 0.02 & 0.061 & 0.089 & 0.046 & 0.051 & 0.044 & 0.066 \\
Variance & 2.931 & 1.591 & 3.322 & 3.887 & 4.833 & 2.311 & 2.248 \\
Std. Dev. & 1.712 & 1.2613 & 1.8226 & 1.9715 & 2.1984 & 1.5201 & 1.4993 \\
Skewness & $-0.404^{* * *}$ & $-1.077^{* * *}$ & $-0.600^{* * *}$ & $-0.810^{* * *}$ & $-0.318^{* * *}$ & $-0.838^{* * *}$ & $-0.183^{* * *}$ \\
Kurtosis & $2.739 * * *$ & $7.416^{* * *}$ & $6.448^{* * *}$ & $6.835^{* * *}$ & $3.211^{* * *}$ & $5.609 * * *$ & $3.201^{* * *}$ \\
JB & $932.865^{* * *}$ & $6820.246^{* * *}$ & $4920.476^{* * *}$ & $5643.727^{* * *}$ & $1225.275^{* * *}$ & $3919.049^{* * *}$ & $1187.004^{* * *}$ \\
ERS & $-5.752^{* * *}$ & $-6.897^{* * *}$ & $-11.331^{* * *}$ & $-9.228^{* * *}$ & $-9.323^{* * *}$ & $-5.999^{* * *}$ & $-16.148^{* * *}$ \\
Q(20) & $16.583^{*}$ & $33.716^{* * *}$ & 10.784 & $24.718^{* * *}$ & $16.728^{*}$ & $19.126^{* *}$ & 13.923 \\
$\mathrm{Q}(20)^{2}$ & $50.817^{* * *}$ & $27.686^{* * *}$ & $49.791^{* * *}$ & $94.666^{* * *}$ & $41.791^{* * *}$ & $35.117^{* * *}$ & $157.174 * * *$ \\
$\mathrm{LM}(20)$ & $114.172^{* * *}$ & $116.734 * * *$ & $56.515^{* * *}$ & $146.417^{* * *}$ & $73.465^{* * *}$ & $105.351^{* * *}$ & $114.471^{* * *}$ \\
\hline
\end{tabular}

Note: The expressions $* * *, * *, *$ show significance at $99 \%, 95 \%$ and $90 \%$ confidence intervals, respectively.

Table 1 presents summary statistics for index values showing the performance of the sectors. Technology, retail-trade, and industry are the sectors with the highest mean returns, respectively. There is a general acceptance in finance theory that high (low) returns can often be associated with high (low) risks. However, as seen in the table, this assumption is not valid for some sectors. For instance, although the finance sector has the lowest mean return, it is among the sectors with high risk (transportation is in the first place, tourism is in the second place) in terms of risk level measured by the standard deviation. It is seen that all series in Table 1 have significant and negative skewness coefficients. Besides, all sectors, except the finance sector, show a significant extreme kurtosis distribution feature. Finally, when the Jargue-Bera (JB) test statistics results are examined, it is seen that all series have non-normal distribution characteristics. The stationarity levels of the series used in the study were examined by the use of the Dickey-Fuller GLS (ERS), ERS Point Optimal test. The null hypothesis in the DF-GLS test is that the series has a unit root. In Table 1, since the calculated ERS test statistic value for each sector's return is less than the critical value, the null hypothesis is rejected, so it is concluded that the series are stationary (Elliott et al., 1996). In the table, $Q(20)$ and $Q(20) 2$ and $A R C H ~ L M(20)$ test results calculated according to the weighted Portmanteau statistics indicate that autocorrelation and ARCH effect exists in the data set.

Table 2. Correlation between Return Series

\begin{tabular}{lccccccc}
\hline & Finance & Industry & Technology & Tourism & Transport & Food & Ret-Tra. \\
\hline Finance & 1.000 & 0.806 & 0.627 & 0.584 & 0.677 & 0.534 & 0.514 \\
Industry & 0.806 & 1.000 & 0.658 & 0.626 & 0.664 & 0.710 & 0.547 \\
Technology & 0.627 & 0.658 & 1.000 & 0.528 & 0.575 & 0.450 & 0.391 \\
Tourism & 0.584 & 0.626 & 0.528 & 1.000 & 0.511 & 0.453 & 0.383 \\
Transport & 0.677 & 0.664 & 0.575 & 0.511 & 1.000 & 0.431 & 0.372 \\
Food & 0.534 & 0.710 & 0.450 & 0.453 & 0.431 & 1.000 & 0.434 \\
Ret-Tra. & 0.514 & 0.547 & 0.391 & 0.383 & 0.372 & 0.434 & 1.000 \\
\hline
\end{tabular}

In the study, correlation analysis was made in order to determine the degree of the relationship between sectors. Calculated correlation coefficients are included in Table 2. Table 2 shows a positive correlation between all sector returns. However, the highest correlation coefficient $(80 \%)$ was calculated between the financial and industrial sectors. The lowest correlation (37\%) was found between the transportation and retail- trade sectors. This wide difference between the correlations ( 0.37 and 0.80 ) makes it more important to analyze the 
dynamic connections between sectors and how shocks and volatility spill over among sectors within the motivation of the study.

\section{Empirical Results and Discussion}

This part of the study reveals empirical findings of the connectedness relationship detected between variables in a network system consisting of sectors. First, the average total (static and dynamic) connectedness results are given. Here, it is discussed which sectors are the net transmitters of shocks and volatility and which are the net recipients of shock and volatility. Secondly, we focus on dynamic interconnectedness results in order to detect the events that may have potential effects on each sector during the analyzed time period and to explain the effect of each on the sectors addressed over time. Finally, the estimated pairwise connectedness results are presented in order to determine the pairwise relations between the constructed sector networks.

Static and dynamic return spillover index results between analyzed sector indices are given in Table 3 and Table 4. While each row of Table 3 and Table 4 corresponds to individual contributions from other sectors to the error variance of the relevant sector, each column corresponds to the respective sector's individual contributions to the error variance of other sectors. The net spillover values in the bottom row of Table 3 and Table 4 express the net shock transmitter (positive value) or net shock receiver (negative value) status of the relevant data.

Table 3. Static Connectedness between Sector Returns

\begin{tabular}{lcclccccc}
\hline & Finance & Industry & Technology & Tourism & Transport & Food & Ret-Tra. & From \\
\hline Finance & 29.356 & 19.141 & 11.628 & 10.089 & 13.451 & 8.527 & 7.807 & 70.644 \\
Industry & 17.493 & 26.847 & 11.618 & 10.533 & 11.882 & 13.576 & 8.051 & 73.153 \\
Technology & 14.119 & 15.476 & 35.735 & 10.019 & 11.852 & 7.265 & 5.534 & 64.265 \\
Tourism & 13.064 & 14.958 & 10.652 & 37.969 & 10.024 & 7.797 & 5.536 & 62.031 \\
Transport & 16.250 & 15.657 & 11.790 & 9.312 & 35.396 & 6.672 & 4.924 & 64.604 \\
Food & 11.308 & 19.625 & 7.861 & 7.951 & 7.311 & 38.525 & 7.419 & 61.475 \\
Ret-Tra. & 12.134 & 13.645 & 7.024 & 6.715 & 6.373 & 8.621 & 45.489 & 54.511 \\
To Others & 84.367 & 98.503 & 60.572 & 54.619 & 60.893 & 52.458 & 39.271 & 450.68 \\
Net spillover & 13.723 & 25.350 & -3.693 & -7.412 & -3.711 & -9.016 & -15.240 & 64.383 \\
\hline
\end{tabular}

Note: $\operatorname{Lag}(1)$, AlC.

According to Table 3, the average Total Connectedness Index (TCI) is $64.4 \%$. According to the results in Table 3, finance and industry sectors are net shock transmitters (positive net spillover), other sectors are net shock receivers (negative net spillover). The top three sectors where the finance sector affects based on shock at most are industry (17.493), transportation (16.250), and technology (14.119), respectively. Also, the top three sectors where the industrial sector affects based on shock at most are food (19.625), finance (19.141), and transportation (15.657) sectors. Static Diebold Yilmaz Spillover Index results do not take into account the change of these relationships base on time. Therefore, Table 5 shows the results based on the time-varying relationship. 
Table 4. Dynamic Connectedness between Sector Returns

\begin{tabular}{lcccccccc}
\hline & Finance & Industry & Techno. & Tourism & Transport & Food & Trade & From \\
\hline Finance & 29.929 & 19.048 & 11.356 & 9.646 & 13.813 & 8.272 & 7.937 & 70.071 \\
Industry & 17.651 & 27.836 & 11.222 & 10.078 & 11.967 & 13.185 & 8.062 & 72.164 \\
Technology & 13.673 & 14.664 & 38.212 & 9.520 & 11.490 & 6.544 & 5.897 & 61.788 \\
Tourism & 12.400 & 14.222 & 10.143 & 40.675 & 9.509 & 7.174 & 5.877 & 59.325 \\
Transport & 16.483 & 15.293 & 11.331 & 8.698 & 36.207 & 6.412 & 5.576 & 63.793 \\
Food & 10.968 & 19.200 & 7.214 & 7.200 & 7.208 & 41.249 & 6.960 & 58.751 \\
Ret-Tra. & 11.839 & 12.992 & 7.272 & 6.936 & 6.945 & 7.903 & 46.113 & 53.887 \\
To Others & 83.014 & 95.419 & 58.538 & 52.077 & 60.931 & 49.489 & 40.309 & 439.77 \\
Net spillover & 12.942 & 23.255 & -3.249 & -7.248 & -2.862 & -9.261 & -13.577 & 62.825 \\
\hline
\end{tabular}

Note: Lag(1), AIC, Forecast Horizon:10, Rolling Window:200

According to the dynamic model results (Table 4), there is no change in the sectors whether they are net shock transmitters and net shock recipients, although the coefficients are different sizes. Accordingly, the financial and industrial sectors are in the net shock transmission position and other sectors are in the net shock recipient position.

The most significant purpose in establishing the dynamic model is to visually analyze the progress of the Total Connectedness Index based on time. Thus, together with the events occurring in the sampling period, the impact of crisis periods and structural changes on the connectedness levels of the sectors can be analyzed based on time.

Figure 3. Dynamic Total Connectedness Index

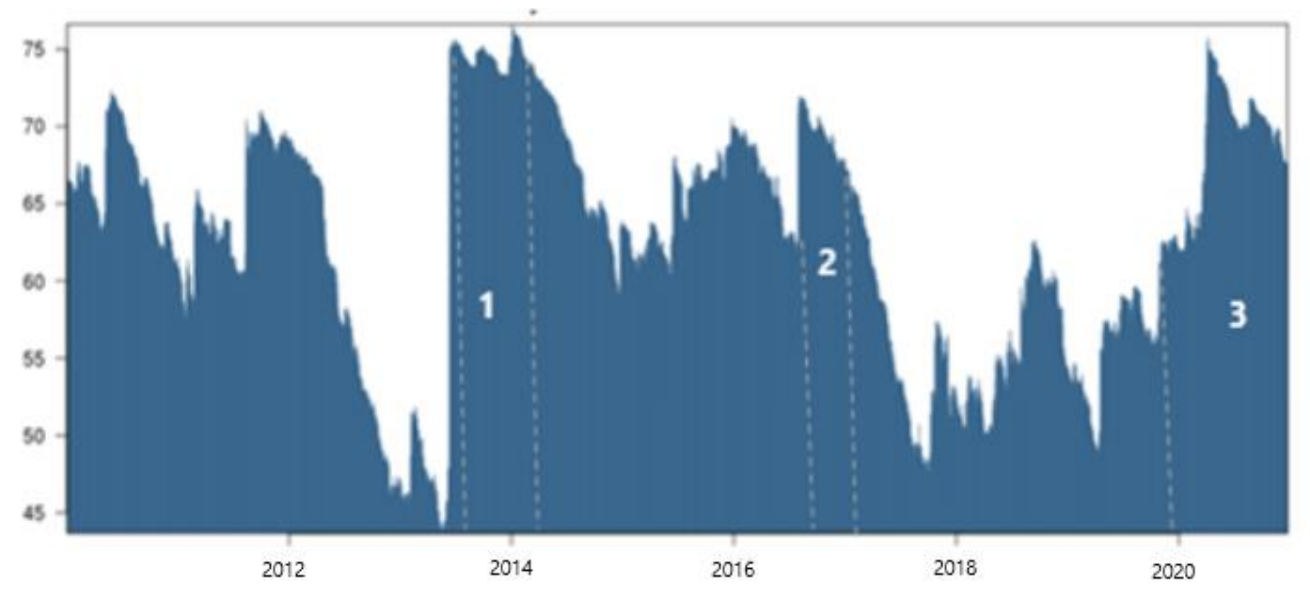

When the graphic in Figure 3 is examined, it is understood that the shock spillover in the system is strengthened in certain periods. During the 1st Period, a terrorist attack was organized in Reyhanlı in which 52 people died, Gezi Park incidents took place and the 17-25 December Operations were carried out. During the 2 nd period, the 15 July coup attempt occurred. During the 3rd period, the COVID-19 pandemic process was experienced. In line with these statements, it is understood that when uncertainty and volatility in the market increase, the shock spillover in the system increases. In cases where the shock spillover in the 
system decreases, it is observed that the sector index volatilities also decrease and the sector indices diverge during this process.

Another important advantage of the Diebold Yılmaz method is that it allows different sectors within the economy to be separated into net shock transmitter and net shock recipient sectors. In other words, a classification for various economic sectors can be obtained with the time-varying parameter (TVP) connectedness approach. In this context, two-stage results can be presented. First, the role of each sector on the total shock in the system (net total connectedness) can be determined during the analysis period. Secondly, net pairwise connectedness analysis can be conducted to explain the dependency relationship between specific industry pairs. In addition, when the dynamic aspect of the analysis is taken into account, it is possible to observe the net shock transmission and net shock recipient position of a sector in the course of time.

The net total directional connectedness of the sectors depend on time is shown in Figure 4. In all figures, positive values correspond to sectors that are involved in net transmission and negative values correspond to sectors that are involved in net reception.

Figure 4. Net Total Directional Return Connectedness
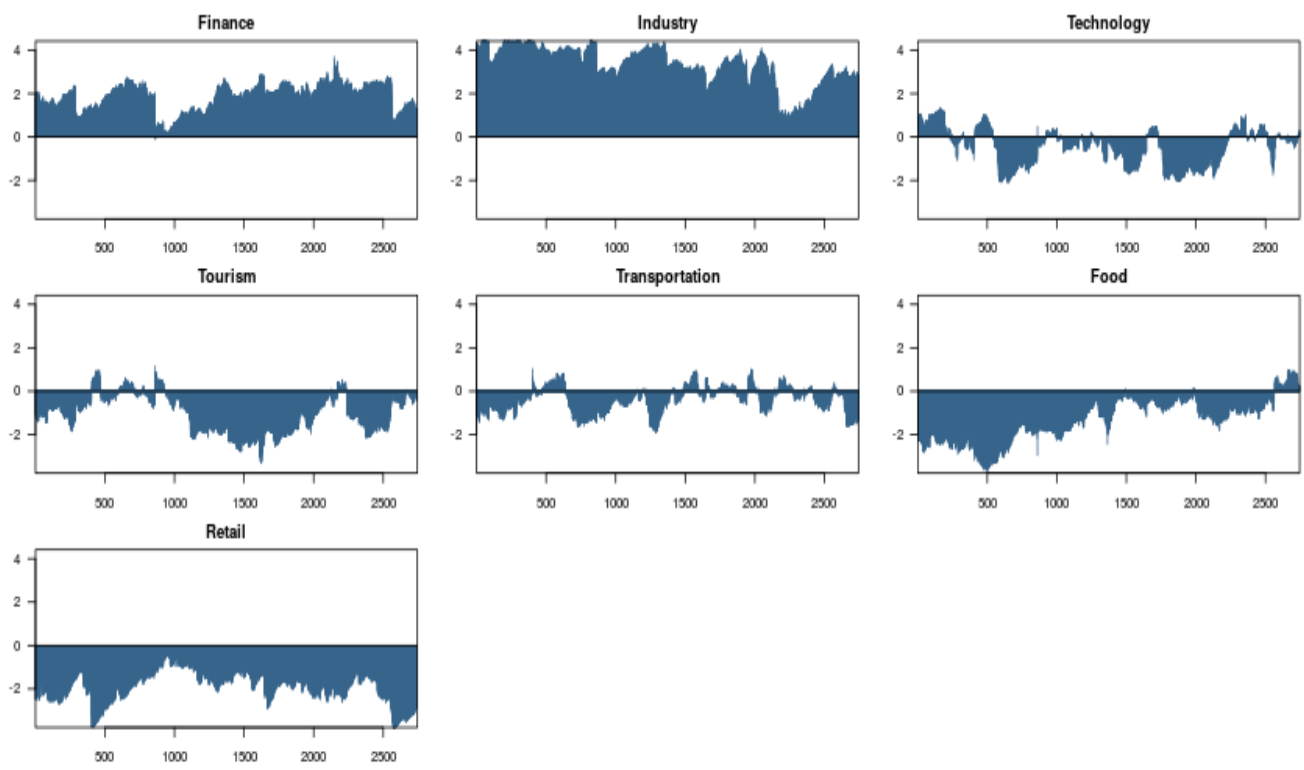

In Figure 4, it can be seen that the finance and industry sectors have been persistent in the net shock transmission position within the total spillover index throughout the entire period. The retail-trade sector, on the other hand, is in the position of a net shock receiver and maintains this effect over time. In addition, tourism, transportation, and food sectors (during the COVID-19 period) show net shock transmitter role in very short periods and low levels, but mainly their role is net shock receiver.

In Figure 5 and Figure 6, the change of the net pairwise directional connectedness coefficients of the financial sector and the industrial sector with other sectors over time is shown. Net pairwise connectedness charts among other sectors are presented in Appendix-A. 
Figure 5. Net Pairwise Directional Return Connectedness of Finance Sector

Finance-Industry

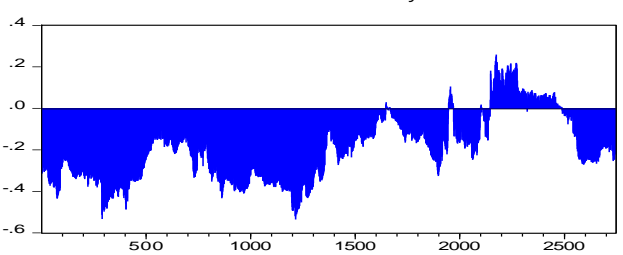

Finance-Tourism

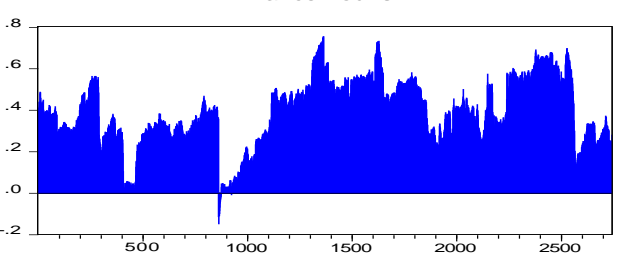

Finance-Food

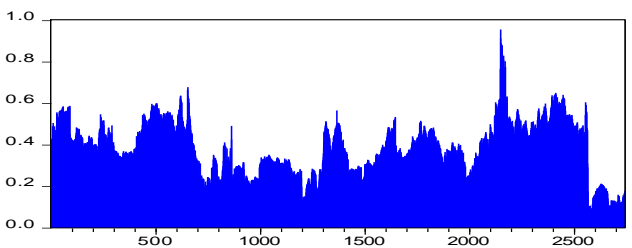

Finance-Technology

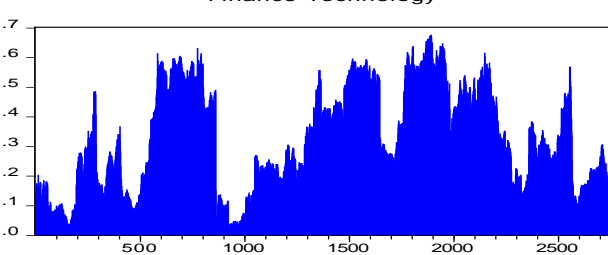

Finance-Transportation

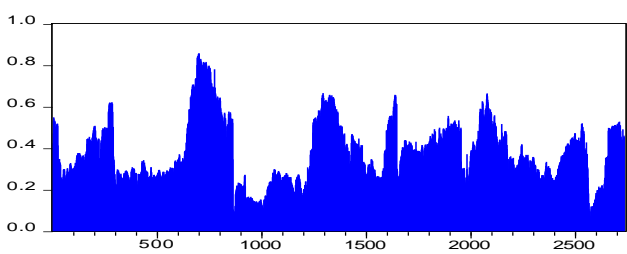

Finance-Retail

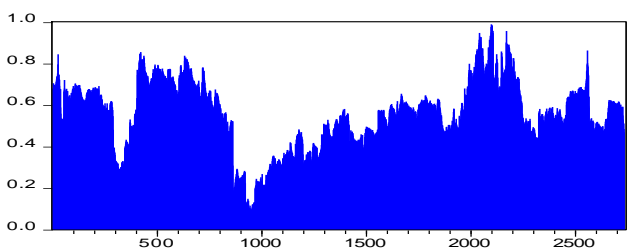

Figure 6. Net Pairwise Directional Return Connectedness of Industry Sector

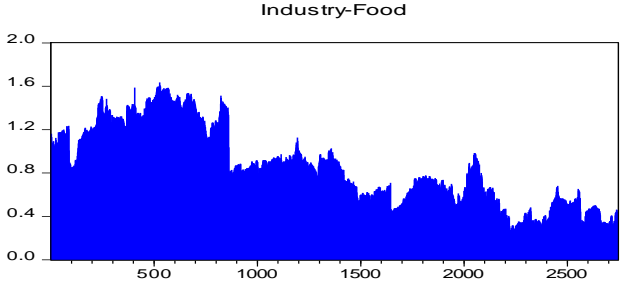

Industry-Retai

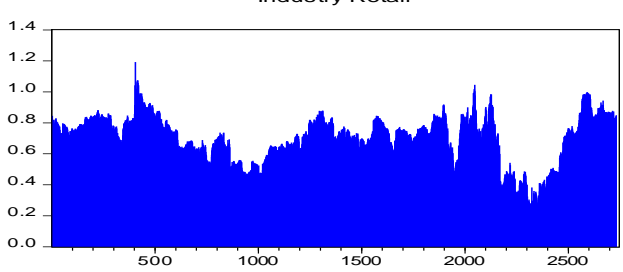

Industry-Technology
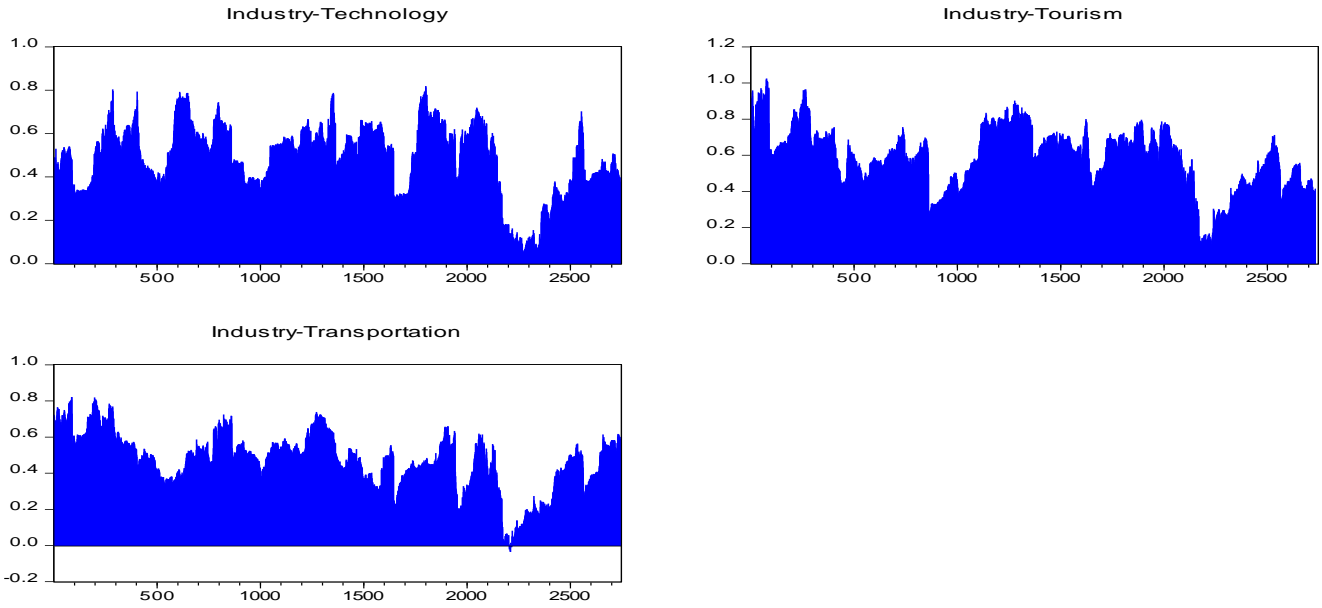
Although there are fluctuations in the course of time according to Figure 5 and Figure 6, the finance sector (excluding its relation with the industrial sector) and the industrial sector are played net shock transmission role in their pairwise relations with all sectors during the period under consideration.

After shock spillover, the spillover relationship between volatilities among industry indices is analyzed. For the analysis of volatility spillover, realized volatility values were calculated by use of the squares of the return series. The changes of the calculated volatility values over time are shown in Figure 7. In the figure, it seems that minor changes are followed by minor changes, and major changes are followed by major changes, which are explained by the volatility clustering.

Figure 7. Return Square Series' Graphic
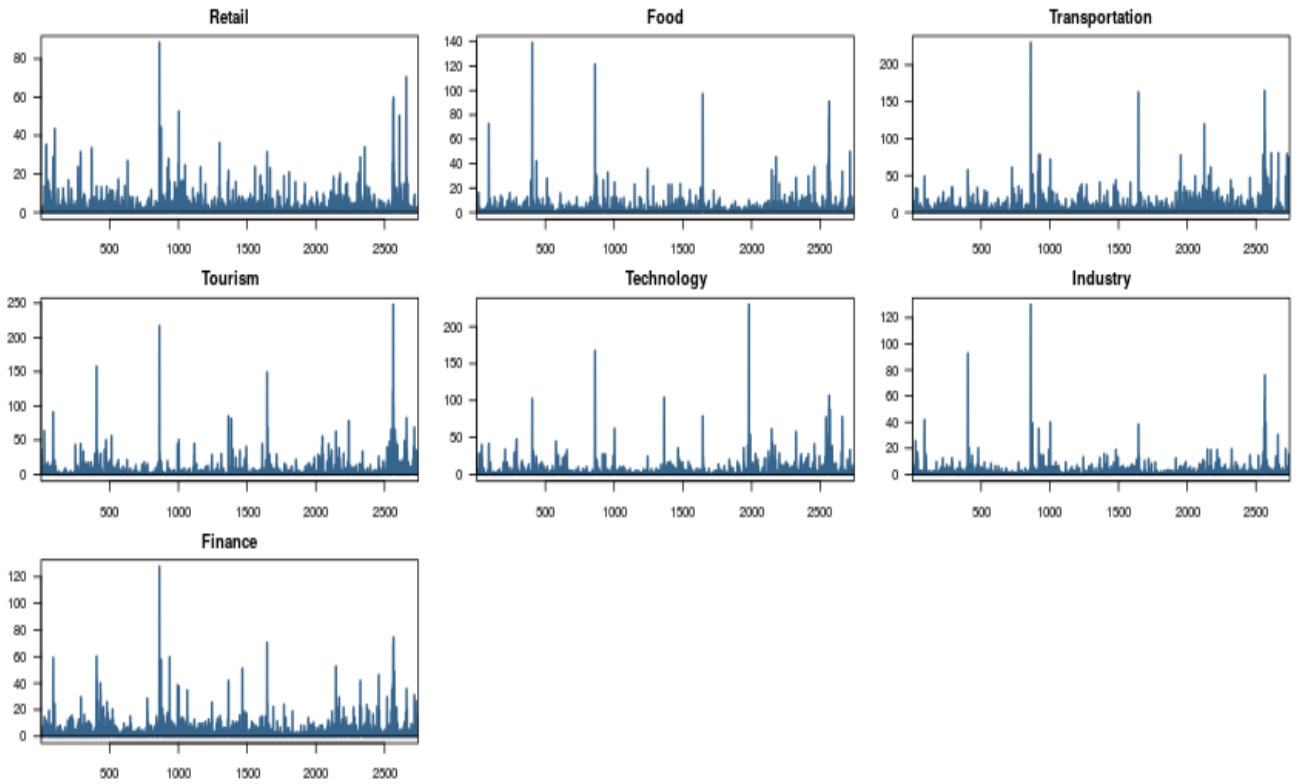

Static volatility connectedness between industry indices is given in Table 6 .

Table 5. Static Connectedness between Sector Volatilities

\begin{tabular}{lcccccccc}
\hline & Finance & Industry & Technology & Tourism & Transport & Food & Ret-Tra. & From \\
\hline Finance & 29.208 & 18.021 & 9.715 & 11.817 & 11.921 & 11.748 & 7.570 & 70.79 \\
Industry & 15.898 & 25.586 & 10.035 & 13.152 & 11.384 & 15.720 & 8.225 & 74.414 \\
Technology & 12.340 & 14.450 & 37.060 & 11.414 & 9.704 & 9.372 & 5.660 & 62.940 \\
Tourism & 12.516 & 15.842 & 9.291 & 32.718 & 10.617 & 12.785 & 6.232 & 67.282 \\
Transport & 13.778 & 15.021 & 9.077 & 11.758 & 34.512 & 9.788 & 6.065 & 65.488 \\
Food & 12.849 & 19.373 & 8.073 & 13.028 & 9.440 & 31.007 & 6.229 & 68.993 \\
Ret-Tra. & 11.081 & 13.773 & 6.263 & 8.411 & 6.923 & 8.271 & 45.278 & 54.722 \\
To Others & 78.462 & 96.480 & 52.453 & 69.581 & 59.989 & 67.684 & 39.981 & 464.631 \\
Net spillover & 7.670 & 22.066 & -10.487 & 2.299 & -5.498 & -1.309 & -14.741 & 66.376 \\
\hline
\end{tabular}

Note: $\operatorname{Lag}(1), A I C$. 
According to Table 5, the Total Connectedness Index is $66.4 \%$. The finance, industry, and tourism sectors play the role of net volatility transmitters, with the industry being the dominant sector in this role. Industry, transportation, and food sectors are the top three sectors on which the finance sector has the greatest impact. The industrial sector, on the other hand, exerts the greatest impact on the food, finance, and tourism sectors. Dynamic volatility connectedness results where time-dependent change is taken into account are given in Table 6.

Table 6. Dynamic Connectedness between Sector Volatilities

\begin{tabular}{lcccccccc}
\hline & Finance & Industry & Technology & Tourism & Transport & Food & Ret-Tra. & From \\
\hline Finance & 33.122 & 17.743 & 10.635 & 10.665 & 10.928 & 10.495 & 6.413 & 66.878 \\
Industry & 15.685 & 30.318 & 10.534 & 11.577 & 10.871 & 14.330 & 6.685 & 69.682 \\
Technology & 11.574 & 13.005 & 41.551 & 11.148 & 9.686 & 7.965 & 5.070 & 58.449 \\
Tourism & 11.032 & 14.176 & 10.701 & 40.987 & 8.564 & 10.215 & 4.325 & 59.013 \\
Transport & 12.718 & 14.255 & 10.189 & 9.233 & 40.591 & 8.631 & 4.383 & 59.409 \\
Food & 11.684 & 17.775 & 8.073 & 10.482 & 7.990 & 38.728 & 5.268 & 61.272 \\
Ret-Tra. & 9.945 & 11.571 & 6.995 & 6.392 & 6.028 & 7.264 & 51.806 & 48.194 \\
To Others & 72.638 & 88.526 & 57.128 & 59.497 & 54.066 & 58.899 & 32.144 & 422.898 \\
Net spillover & 5.759 & 18.844 & -1.321 & 0.483 & -5.342 & -2.373 & -16.050 & 60.41 \\
\hline
\end{tabular}

Note: $\operatorname{Lag}(1)$, AIC, Forecast Horizon:10, Rolling Window:200

According to the results in Table 6, in the net volatility (information-risk) spillover, there are finance, industry, and tourism sectors, albeit at a very low level. The results obtained from Table 6 are very similar to the results obtained from the static method. When the results obtained from the shock spillover are compared with the results obtained from the volatility spillover, again a great similarity is encountered. The graphs regarding the net volatility (information) transmission or recipient role of the sector indices that depend on time are shown in Figure 8.

Figure 8. Net Total Directional Volatility Connectedness
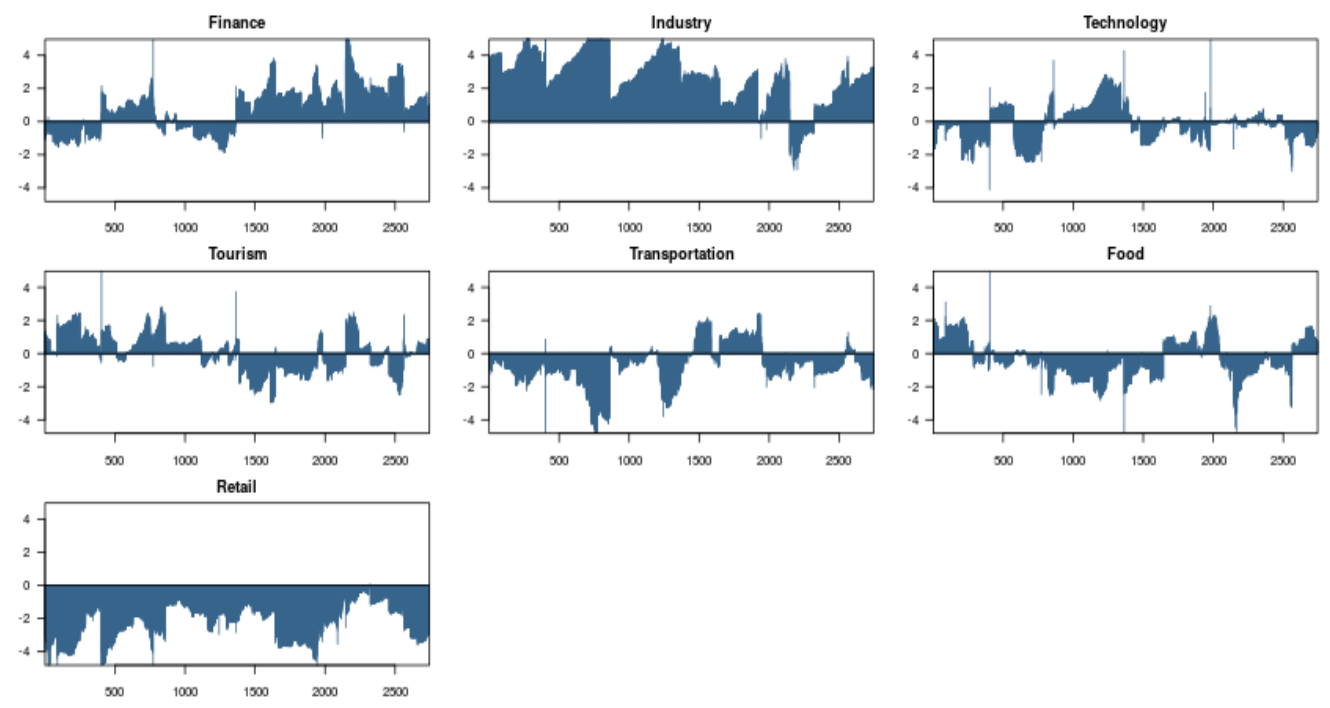
When Figure 8 is examined, it is seen that the industrial sector is dominantly in a net transmission role based on total volatility spillover, except for a very short period of time. The finance sector, on the other hand, appears to be a net volatility recipient in certain periods between 2010 and 2015, but it has assumed the role of net volatility transmission after 2015 .

In Figure 9 and Figure 10, the change of net pairwise directional connectedness coefficients of the financial sector and the industrial sector with other sectors over time is shown. Net pairwise connectedness charts between other sectors are presented in AppendixB.

Figure 9. Net Pairwise Directional Volatility Connectedness of the Finance Sector
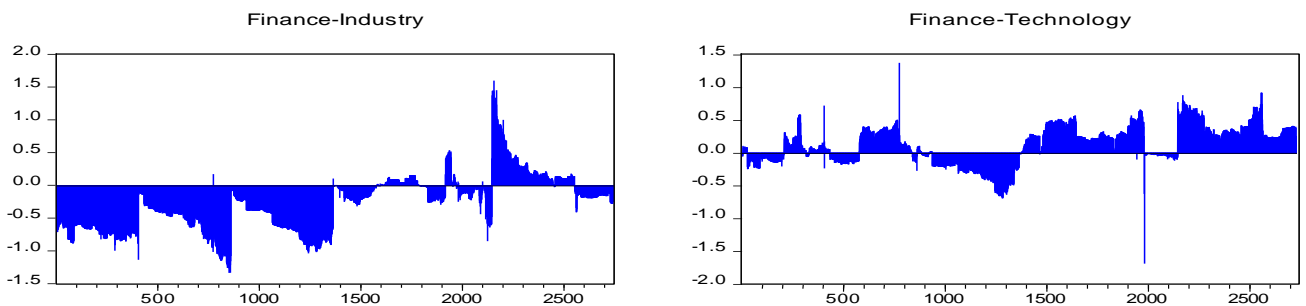

Finance-Tourism
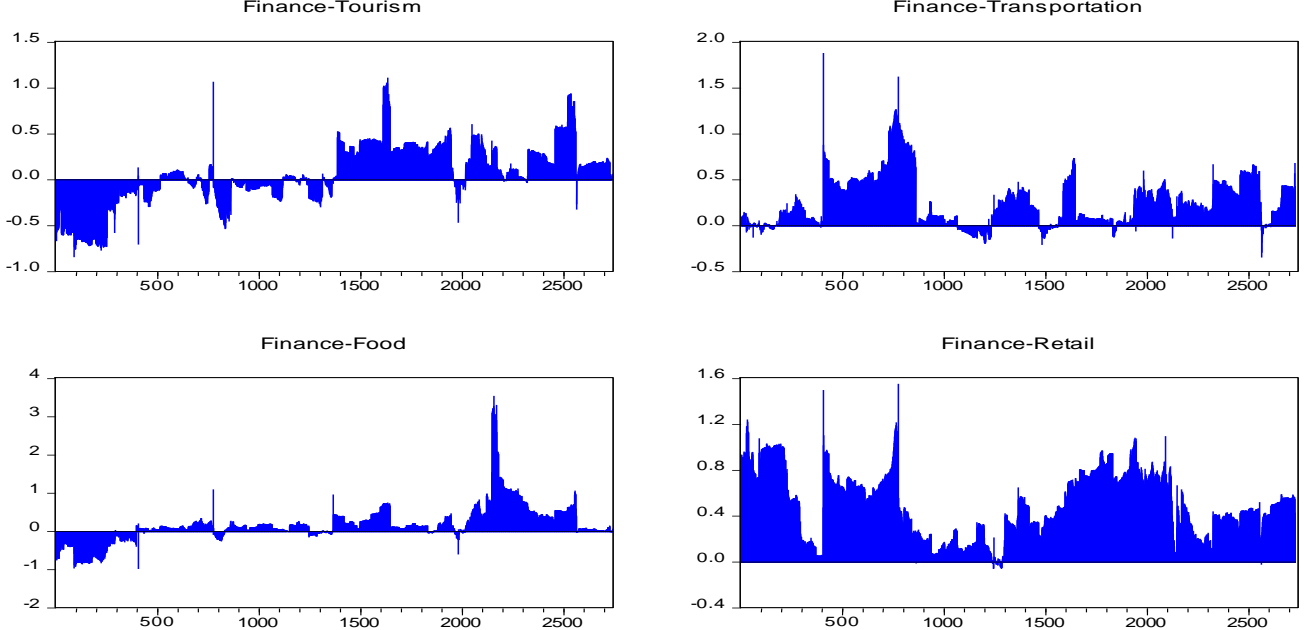
Figure 10. Net Pairwise Directional Volatility Connectedness of Industry Sector

Industry-Food

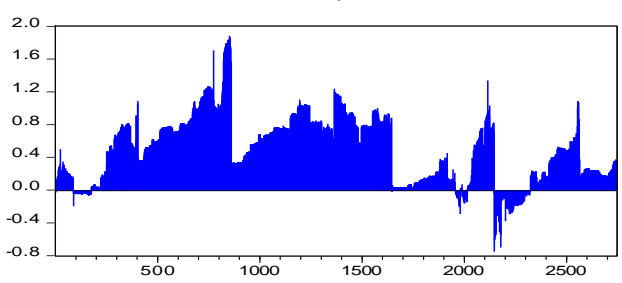

Industry-Technology

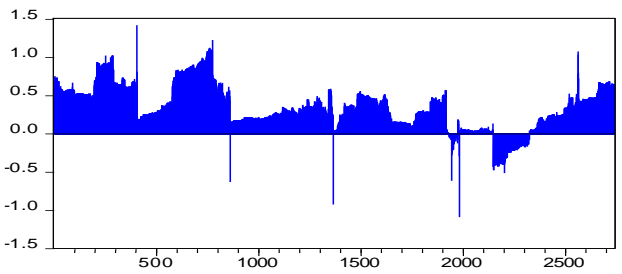

Industry-Transportation

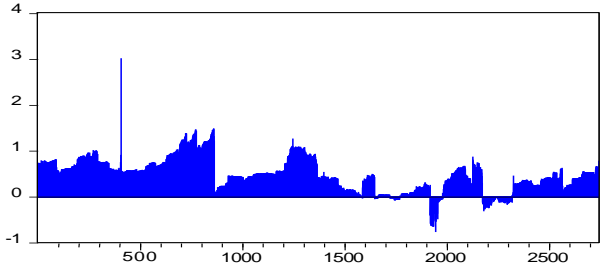

Industry-Retail

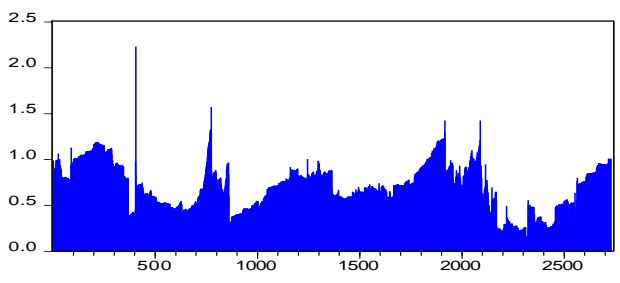

Industry-Tourism

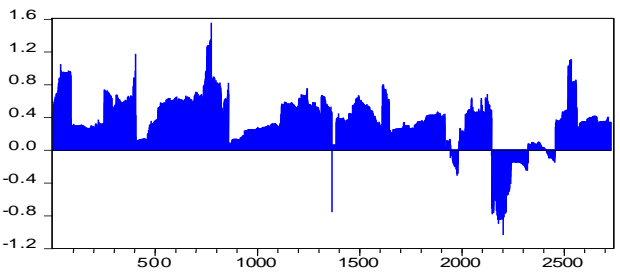

According to Figure 9 and Figure 10, the finance sector (excluding its relationship with the industrial sector) and the industrial sector are predominantly net volatility transmitters in their pairwise relations with other sectors.

As a result of the analyses made, the industry and finance sectors are in the leading sector, coinciding with the theoretical expectations. Considering that the main components of economic growth are increases in production and capital stock, it is an expected result that the industry and finance sectors are the main drivers of economic growth. However, it is not clear which of the leading indicators, industry or finance, is more dominant. It is concluded that this situation depends on the economic cycle when we consider other studies in the literature. For the Turkish economy, the industry sector dominated the period between 20102018. The transformation of the net buyer role of the food sector into a net transmitter role during the COVID 19 period can be explained by the positive demand shock faced by the food sector during this period.

\section{Conclusion}

Analysis of the connectedness between different sectors of the economy is important for policymaking and portfolio management. In this study, the inter-sectoral dependency level is analyzed using the vector autoregressive dynamic connectedness model with time-varying parameters developed by Antonakakis et al. (2019).

As a result of the analysis, it is seen that the shock interaction, which exists throughout the system, escalates in cases of increase in uncertainty and market challenging risks 
(Reyhanlı Terror Attack, 17-25 December Operations, Gezi Park Incidents, 15 July Coup Attempt, COVID-19 pandemic, etc.). In line with the findings of the study, it is determined that the industry and finance sectors are in the position of net shock and volatility transmitters. Besides, both sectors are the industries that exert the most impact and which are affected at most. These results show the leading roles of the industry and the finance sectors on other sector indices (technology, tourism, transportation, food, retail-trade). Wu et al. (2019), Wu (2019), Lastrapes - Wiesen (2020), and Yin (2020) determined that the industrial sector has an essential role for the countries analyzed. Vardar et al. (2012) determined that the banking sector is the most important sector for Turkey. However, it was observed that the industrial sector was not taken into consideration in this study. According to the static and dynamic analysis, the first two sectors that the industrial sector exerts impact by means of shock (relationship at the level of return) and volatility are respectively food and finance. The sector it has the least impact on is the retail - trade sector. The first two sectors that the finance sector exerts impact by means of shock and volatility are industry and transportation respectively. With respect to the pairwise shock and volatility relationship between industry and finance sector, the finance sector plays a major role as the net recipient. The retail-trade industry is the index that makes the least contribution to the total shock and volatility spillover in the system. The technology sector, on the other hand, plays the role of a net shock and volatility recipient. The technology sector is most affected by the industry and finance sectors in terms of shock and volatility spillover, and it has the highest impact on the finance sector. In the pairwise relationship between technology and the finance sector, the finance sector is predominantly a shock and volatility transmitter. When an evaluation is made regarding the COVID-19 period, the most interesting result is experienced in the food sector. The food sector, which is predominantly a shock and volatility receiver, becomes a shock and volatility transmitter in the relevant period. In terms of pairwise relations, this situation is realized with the retail-trade sector.

Diebold and Yilmaz's $(2009,2012)$ approach can be used as an input and output table in a time-series dimension. The sector that shocks in this respect is also the sector that provides basic inputs. According to the findings in the table, the industry and finance sectors are the main sectors that shocked. Therefore, it is a forward-linkage sector. Other sectors are backward-linkage sectors since they receive shocks. This situation can be considered a reflection of real relations in financial markets in terms of economics technique. The sectoral diversification has a shock-absorbing feature when we consider this point of view. The main indicator of this is that the degree of shock received by the financial and industrial sectors from sub-sectors is far below what it gives. As a result, it can be expected that the impact of shocks will spread and decrease through the diversity of sub-sectors, as long as there is no external shock in the Turkish economy.

Analysis of the connectedness between different sectors of the economy is important for policymaking and portfolio management. In the study, the industry and finance sector is observed as leading and other sectors as lagging. This result guides policymakers to develop a policy through the industry and finance sectors. For instance, policymakers may act by considering that an important incentive decision for the industrial sector may affect the food and finance sectors most, or that a decision to be taken for financial stability and monetary policy will have the most impact on the industry and transportation sectors by dint of financial sector. For this reason, it is thought that the inter-sectoral connectedness analysis 
conducted will guide policymakers in sector-oriented policies. The results obtained help investors in the creation of the portfolio process. Investors can have opportunities for appropriate diversification by taking advantage of the shock and information transmission mechanism.

It is elaborated that if future studies on the subject differ from two aspects, a clearer perspective will be attained. These are - the calculation of effective hedging ratios and optimal portfolio weights. It is considered appropriate to use up-to-date techniques (Copula) that take into account the dependency structure whilst making these calculations. 


\section{References}

Ahmed, W. M. A. (2016), "The Dynamic Linkages Among Sector Indices: The Case Of The Egyptian Stock Market", International Journal of Economics and Finance, C. 8, S. 4: 23-38.

Antonakakis, N.; Cunado J.; Filis G.; Gabauer, D.; De Gracia F. P. (2019), "Oil And Asset Classes Implied Volatilities: Dynamic Connectedness And Investment Strategies", Energy Economics Forthcoming.

Arbelaez, H.; Urrutia, J.; Abbas, N. (2001), "Short-Term And Long-Term Linkages Among The Colombian Capital Market Indexes", International Review of Financial Analysis, C. 10: 237-273.

Arouri, M. E. H.; Jouni, J.; Nguyen, D. K. (2012), "On The Impacts Of Oil Price Fluctuations On European Equity Markets: Volatility Spillover And Hedging Effectiveness", Energy Economics, C. 34: 611617.

Bai, S.; Koong, K. S. (2018), "Oil Prices, Stock Returns, And Exchange Rates: Empirical Evidence From China And The United States", North American Journal of Economics and Finance, C. 44: 12-33.

Balcılar, M.; Ozdemir, Z. A.; Ozdemir, H. (2019), "Dynamic Return And Volatility Spillovers Among S\&P 500, Crude Oil, And Gold", International Journal of Finance \& Economics: 1-18.

Barunik, J.; Kocenda, E.; Vacha, L. (2015), “Asymmetric Connectedness On The U.S. Stock Market: Bad And Good Volatility Spillovers", Journal of Financial Markets, C. 27: 55-78.

Basher, S. A.; Sadorsky, P. (2016), "Hedging Emerging Market Stock Prices With Oil, Gold, VIX, And Bonds: A Comparison Between DCC, ADCC And GO-GARCH", Energy Economics, C. 54: 235-247.

Baumöhl, E.; Kocenda, E.; Lyocsa, S.; Vyrost, T. (2018), "Networks Of Volatility Spillovers Among Stock Markets", Physica A, C. 490: 1555-1574.

Belhassine, O. (2020), "Volatility Spillovers and Hedging Effectiveness Between The Oil Market And Eurozone Sectors: A Tale Of Two Crises", Research in International Business and Finance, C. 53: 1-39.

Cavaglia, S.; Brightman, C.; Aked, M. (2000), "The Increasing Importance of Industry Factors", Portfolio Management: 41-54.

Chakrabarty, A.; De, A.; Bandyopadhyay, G. (2015), "A Wavelet-Based MRA-EDCC-GARCH Methodology For The Detection Of News And Volatility Spillover Across Sectoral Indices: Evidence From The Indian Financial Market", Global Business Review, C.16, S.1: 35-49.

Chatziantoniou, I.; Gabauer, D.; Marfatia, H. (2020), "Dynamic Contentedness and Spillovers Across Sectors: Evidence From Indian Stock Market", Working Paper.

Chen, Y.; Li, W.; Qu, F. (2019), "Dynamic Asymmetric Spillovers And Volatility Interdependence On China's Stock Market", Physica A, C. 523: 825-838.

Creti, A.; Joets, M.; Mignon, V. (2013), “On The Links Between Stock And Commodity Markets' Volatility", Energy Economics, C. 37: 16-28.

Diebold, F. X.; Yilmaz, K. (2009), "Measuring Financial Asset Return And Volatility Spillovers, With Application To Global Equity Markets", The Economic Journal, C. 119, S. 534; 158-171.

Duncan, A. S.; Kabundi, A. (2013), "Domestic and Foreign Sources Of Volatility Spillover To South African Asset Classes", Economic Modelling, C. 31: 566-573.

Duran, S.; Sahin, A. (2006), "The Relationship Among IMKB Services, Financial, Industrial And Technological Indices", The Journal of Social Sciences Research, C. 1, S.1: 57-69.

Elliott, G.; Rothenberg, T.; Stock, J. H. (1996), "Efficient Tests for an Autoregressive Unit Root", Econometrica, C. 64: 813-836.

Eyuboglu, S.; Eyuboglu, K. (2019), "Testing the interdependence of Borsa Istanbul Sector Indices", Erciyes University Journal of Faculty of Economic and Administrative Sciences, C. 53: 246-260. 
Ewing, B. T. (2002), "The Transmission Of Shocks Among S\&P Indexes". Applied Financial Economics, C. $12: 285-290$.

Hammoudeh, S. M.; Yuan, Y.; McAleer, M. (2009). "Shock And Volatility Spillovers Among Equity Sectors Of The Gulf Arab Stock Markets", The Quarterly Review of Economics and Finance, C. 49: 829842.

Hassan, S. A.; Malik F. (2007), "Multivariate GARCH Modeling Of Sector Volatility Transmission", The Quarterly Review of Economics and Finance, C. 47: 470-480.

Hassan, K.; Hoque, A.; Wali, M.; Gasbarro, D. (2020). "Islamic Stocks, Conventional Stocks, And Crude Oil: Directional Volatility Spillover Analysis In BRICS", Energy Economics, C. 92: 1-16.

Jebran, K.; Chen, S.; Ullah, I.; Mirza, S. S. (2017), "Does Volatility Spillover Among Stock Markets Varies From Normal To Turbulent Periods? Evidence From Emerging Markets Of Asia", The Journal of Finance and Data Science, C. 3, S. 4: 20-30.

Kang, W.; Ratti, R. A.; Yoon, K. H. (2015), "The Impact Of Oil Price Shocks On The Stock Market Return And Volatility Relationship", Journal of International Financial Markets, Institutions \& Money, C. 34: 41-54.

Khalfaoui, R.; Sarwar, S.; Tiwari, A. K. (2019), "Analysing Volatility Spillover Between The Oil Market And The Stock Market In Oil-Importing And Oil-Exporting Countries: Implications On Portfolio Management", Resources Policy, C. 62: 22-32.

Kırkpınar, A. (2019), "Measurement Of Volatility Spillover Between Sector Indices In Borsa Istanbul With Multivariate GARCH Model", Global Journal of Economics and Business Studies, C. 8, S. 16: 140148.

Kocaarslan, B. (2020), "Volatility Interaction Between BIST (Borsa Istanbul) Technology Index And Other Main Sector Indices", Business \& Management Studies: An International Journal, C. 8, S. 1: 458475.

Kouki, I.; Harrathi, N.; Haque, M. (2011), "A Volatility Spillover Among Sector Index Of International Stock Markets", Journal of Money, Investment and Banking, C. 22: 32-45.

Li, Y. L.; Giles, D. E. (2014), "Modellıng Volatility Spillover Effects Between Developed Stock Markets And Asian Emerging Stock Markets", International Journal of Finance \& Economics: 1-22.

Malik, F.; Ewing, B. T. (2009), "Volatility Transmission Between Oil Prices And Equity Sector Returns", International Review of Financial Analysis, C. 18: 95-100.

Malkiel, B. G. (1989), “Is the Stock Market Efficient?" Science, C. 243, S. 4896: 1313-1318.

Mandacı, P. E.; Cagli, E.Ç.; Taşkın, D. (2020), "Dynamic Connectedness And Portfolio Strategies: Energy And Metal Markets", Resources Policy, C. 68: 1-16.

Mateus, C.; Chinthalapati, R.; Mateus, I. B. (2017), "Intraday Industry-Specific Spillover Effect In European Equity Markets", The Quarterly Review of Economics and Finance, C. 63: 278-298.

Mensi, W.; Beljid, M.; Boubaker, A.; Managi, S. (2013). “Correlations And Volatility Spillovers Across Commodity And Stock Markets: Linking Energies, Food, And Gold", Economic Modelling, C. 32: 15-22.

Mensi, W.; Hammoudeh, S.; Nguyen, D. K.; Kang, S. H. (2016), "Global Financial Crisis And Spillover Effects Among The U.S. And BRICS Stock Markets", International Review of Economics \& Finance, C. 42: 257-276.

Mensi, W.; Nekhili, R.; Vo, X.V.; Suleman, T.; Kang, S. H. (2020), "Asymmetric Volatility Connectedness Among U.S. Stock Sectors", North American Journal of Economics \& Finance: 1-46.

Nazlıoglu, S.; Soytas, U.; Gupta, R. (2015), "Oil Prices And Financial Stress: A Volatility Spillover Analysis", Energy Policy, C. 8: 278-288.

Patra, T.; Poshakwale, S. S. (2008), "Long-Run And Short-Run Relationship Between The Main Stock Indexes: Evidence From The Athens Stock Exchange", Applied Financial Economics, C. 18: 1401-1410. 
Singh, P.; Kumar, B.; Pandey, A. (2010), "Price And Volatility Spillovers Across North American, European And Asian Stock Markets", International Review of Financial Analysis, C. 19: 55-64.

Stiglitz, J. E. (1981), "Information and Capital Market". National Bureau of Economic Research Working Paper: 1-55.

Şenol, Z. (2020), "Volatility Spillover Among Stock Market Sectors". Gazi Journal of Economics \& Business, C. 6, S.3: 257-267.

Tokat, E. (2010). "Shock And Volatility Interaction Between The Sector Indexes Of Istanbul Stock Exchange", Journal of BRSA Banking and Financial Market, C. 4, S. 1: 91-104.

Topaloglu, E. E. (2020), "Volatility Structure And Volatility Spillover Of Borsa Istanbul Stock Indexes: The Case Of BIST Industrial And Financial Indexes With GARCH And MGARCH Models", Dumlupınar University Journal of Social Sciences, C. 63:17-38.

Vardar, G.; Tunc, G.; Aydogan, B. (2012), "Long-Run And Short-Run Dynamics Among The Sectoral Indices: Evidence From Turkey", Asian Economics and Financial Review, C. 2, S. 2: 347-357.

Wang, Z. (2010), "Dynamics And Causality In Industry-Specific Volatility", Journal of Banking \& Finance, C. 34: 1688-1699.

Wang, Z.; Kutan, A. M.; Yang, J. (2005), "Information Flows Within And Across Sectors In Chinese Stock Markets", The Quarterly Review of Economics and Finance, C. 45: 767-780.

Xiao, L.; Dhesi, G. (2010), "Volatility Spillover And Time-Varying Conditional Correlation Between The European And US Stock Market", Global Economy and Finance Journal, C. 3, S.2: 148-164.

Yin, K.; Liu, Z.; Jin, X. (2020). "Interindustry Volatility Spillover Effects In China's Stock”, Physica A, C. 539: 1-15.

Zhang, W.; Zhuang, X.; Wang, J.; Lu, Y. (2020), “Connectedness And Systemic Risk Spillovers Analysis Of Chinese Sectors Based On Tail Risk Network", North American Journal of Economics \& Finance, C.54: $1-24$. 
APPENDIX-1: Net Pairwise Directional Return Connectedness of Sector Indices

Technology-Food

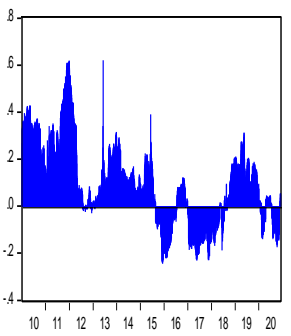

Tourism-Food

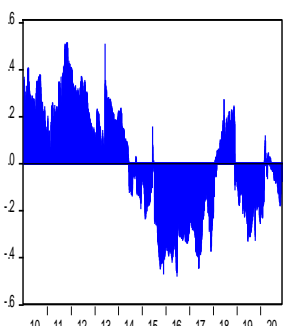

Transportation-Retail

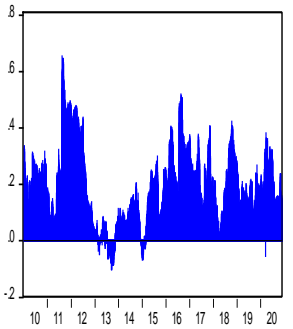

Technology-Retall

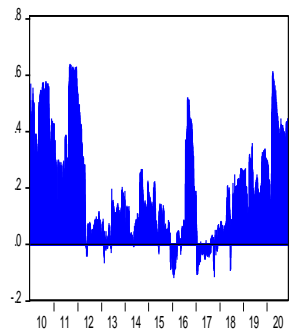

Tourism-Retail

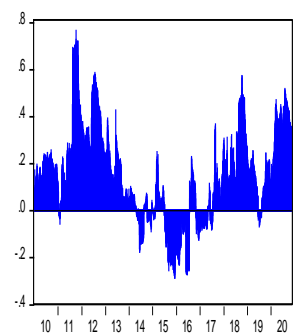

Food-Retal

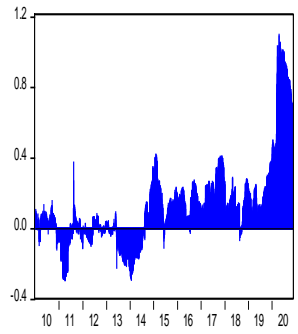

Technobogy-Tourism

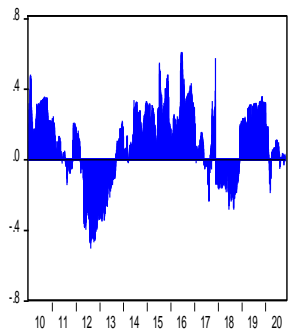

Tourism-Transportation

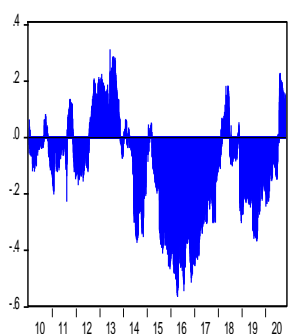

Technology-Transportation

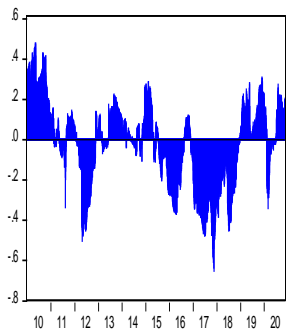

Transportation-Food

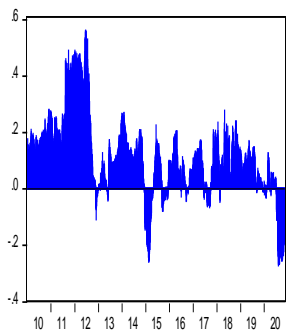


APPENDIX-2: Net Pairwise Directional Volatility Connectedness of Sector Indices
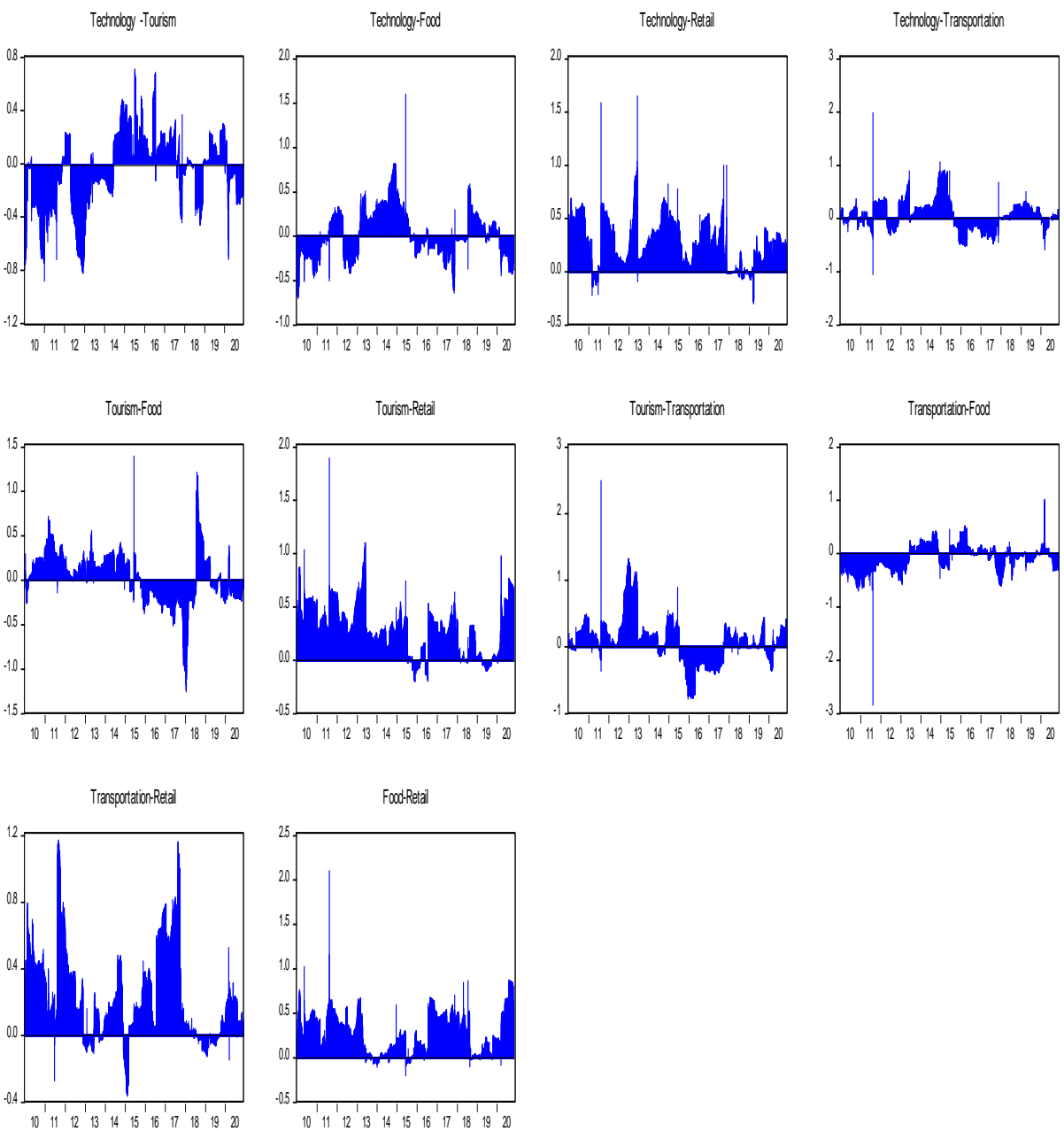